
Andrzej MODRZEJEWSKI ${ }^{3}$

\title{
CHANGES IN UDDER SKIN SURFACE TEMPERATURE OF DAIRY COWS CAUSED BY MACHINE MILKING
}

\section{ZMIANY TEMPERATURY POWIERZCHNIOWEJ WYMIENIA KRÓW MLECZNYCH NA SKUTEK DOJU MECHANICZNEGO}

Department of Horse Breeding and Equestrian Studies, Wroclaw University of Environmental and Life Sciences, Wrocław, Poland

1Department of Ruminants Science, West Pomeranian University of Technology, Szczecin, Poland 2Department of Forensic Medicine, Pomeranian Medical University, Szczecin, Poland

${ }^{3}$ Laboratory of Surgical and Emergency Nursing, Pomeranian Medical University, Szczecin, Poland

\begin{abstract}
Streszczenie. Celem niniejszej pracy było sprawdzenie, czy dój mechaniczny istotnie wpływa na temperaturę powierzchniową wymienia (TPW) krów, dla ustalenia najbardziej optymalnego momentu pomiaru TPW przy detekcji mastitis. W sumie przebadano 21 krów rasy polskiej holsztyńsko-fryzyjskiej odmiany czarno-białej. Termogramy wykonywano dla tylnej i dolnej części wymienia w hali udojowej przed dojem i po nim u tych samych krów. Do wyliczenia średniej temperatury wymienia, jej odchylenia standardowego, minimum i maksimum wykorzystano dwa narzędzia geometryczne (koła i kwadraty) dostępne w programie komputerowym do analizy obrazu. Średnia wartość średniej temperatury w obrębie kół była istotnie większa $(P \leq 0,05)$ przed dojem $\left(36,48^{\circ} \mathrm{C}\right.$ i $36,61^{\circ} \mathrm{C}$ odpowiednio dla prawej i lewej tylnej ćwiartki wymienia) niż po $\operatorname{nim}\left(36,24^{\circ} \mathrm{C}\right.$ i $36,09^{\circ} \mathrm{C}$ odpowiednio dla prawej i lewej tylnej ćwiartki wymienia). Także średnia temperatura w obrębie kwadratów dla lewej tylnej ćwiartki była istotnie wyższa $(P \leq 0,05)$ przed dojem $\left(36,58^{\circ} \mathrm{C}\right)$ niż po nim $\left(35,88^{\circ} \mathrm{C}\right)$. Odnotowano tylko jedną istotną różnicę $(P \leq 0,05)$ wartości temperatury (koła) pomiędzy lewą a prawą tylną ćwiartką (rozstęp temperatury po doju). Podsumowując, pomiar TPW przy potencjalnej detekcji mastitis powinien być zawsze wykonywany w tym samym momencie, gdyż dój istotnie oddziałuje na wartość TPW.
\end{abstract}

Key words: thermography, udder, dairy cows, machine milking, effect, mastitis detection.

Słowa kluczowe: termografia, wymię, bydło mleczne, dój mechaniczny, wpływ, detekcja mastitis.

\section{INTRODUCTION}

Udder skin surface temperature (SST) may be an important indicator of physiological state or disease. SST distribution reflects the processes progressing inside the mammary gland according to the following mechanism: the circulating blood is heated due to the metabolism occurring in the udder tissues and part of this warm blood travels to superficial tissues such as skin, heating them additionally to the heat provided by thermal conduction mechanisms (Vainer 2012). Udder SST may be affected by mastitis (Colak et al. 2008; Polat et al. 2010).

Corresponding author - Adres do korspondencji: Daniel Zaborski, Department of Ruminants Science West Pomeranian University of Technology, Szczecin, Doktora Judyma 10, 71-466 Szczecin, Poland, e-mail: daniel.zaborski@zut.edu.pl 
One of the SST measurement methods is thermography, which is a safe non-contact technique based on the analysis of infrared energy using thermographic camera and an appropriately designed computer program (Kunc and Knizkova 2012; Soroko and Davies-Morel 2016). Infrared thermography has been applied to many areas of dairy cattle husbandry, e.g. the diagnosis of mastitis, kidney infection and pneumonia in Holstein-Friesian cows during oestrus (Hurnik et al. 1984), aseptic arthritis diagnosis in Friesian heifers (Cockcroft et al. 2000), observation of inflammatory changes in hot-iron and freeze brand sites (Schwartzkopf-Genswein et al. 1997), hoof health monitoring, identification of joint injures (Unshelm et al. 1992; Nikkhah et al. 2005), determination of oestrus onset in Holstein-Friesian cows (Hurnik et al. 1985), detection of viral diarrhoea and respiratory disease in calves (Schaefer et al. 2004, 2007), pain identification in disbudded calves (Stewart et al. 2008), analysis of cooling-induced heat stress and general stress in dairy cattle (Kimmel et al. 1992; Knizkova et al. 1996; Stewart et al. 2007) and evaluation of the effect of natural ventilation on cows' thermal comfort (Knížková et al. 2002).

Some applications of infrared thermography also concern detection of clinical and subclinical mastitis (Berry et al. 2003; Colak et al. 2008; Hovinen et al. 2008; Polat et al. 2010; Pezeshki et al. 2011; Metzner et al. 2014). This results from the fact that mastitis as an inflammatory process increases tissue metabolism and therefore is associated with an increased SST. There are few reports on the use of infrared thermography for mastitis detection in the Polish population of dairy cattle. In order to be able to distinguish between healthy and mastitis cases, it is first necessary to examine the effect of different environmental and physiological factors on udder SST so that they do not interfere with the influence of inflammatory state itself.

Therefore, the aim of the present study was to indicate if machine milking significantly affects udder SST in order to establish the most optimum time for SST measurement in mastitis detection.

\section{MATERIAL AND METHODS}

The research involved 21 healthy (without clinical or subclinical mastitis) Polish HolsteinFriesian Black-and-White cows kept on one farm located in the West Pomeranian Province. The cows were housed in a free-stall barn, fed a total mixed ration and milked twice daily (03.30 and 13.00) in a herringbone milking parlour (Afimilk Ltd., Kibbutz Afikim, Izrael). The cows were in their first lactation, 70 to 201 days post calving (mean $=150.1$ days and $S D=33.4$ days). The mean daily milk yield for the current lactation was $32.01 \pm 4.33 \mathrm{~kg}$ (mean and SD, respectively), whereas the mean daily protein and fat yields were $1.04 \pm 0.09 \mathrm{~kg}$ and $1.43 \pm 0.23 \mathrm{~kg}$, respectively. Cow production records were retrieved from the Afifarm program (Afimilk Ltd., Kibbutz Afikim, Izrael) utilized on the farm for herd management. The thermograms of the udder were taken in the milking parlour before and after the morning milking. The temperature inside the milking parlour and the waiting area was approx. $21.3^{\circ} \mathrm{C}$. The animals moved from the waiting area to the milking parlour systematically and the average waiting time did not exceed 20 min. They were milked approx. in the middle of the milking routine. Cow udders were not clipped or extensively cleaned prior to imaging. The teats were immersed in disinfection foam and dried with paper towels. 
Only in the case of excessive dirt, the udders were washed with water, however, it should be stated that the udder cleanliness level of the investigated cows was generally high. The thermograms were recorded from the rear and bottom of the udder when the cows remained inside the milking stalls. Recording was performed after teat cleaning and postdipping.

The VarioCam HR® thermal camera (InfraTec $\mathrm{GmbH}$, Dresden, Germany) was used for this purpose (resolution: $640 \times 480$ pixels, spectral range: $7.5-14.0 \mu \mathrm{m}$, thermal range: $-40-1200^{\circ} \mathrm{C}$, detector: uncooled microbolometer). To control the effect of environmental conditions on the SST value, the distance between the camera and the udder was measured each time using a laser rangefinder. Ambient temperature and humidity inside the milking parlour were recorded using an electronic hygrothermometer (measuring range: $-20-50^{\circ} \mathrm{C}$ ).

The thermograms were analyzed using the IRBIS 3 Professional software (v. 3.1, InfraTec $\mathrm{GmbH}$, Dresden, Germany). The program image resolution was $800 \times 600$ pixels with a 16-bit colour depth. Two geometric tools (a circle with a radius of 50 pixels based on the suggestion of Hovinen et al. (2008) and a square with a side of 100 pixels) were applied to obtain the udder SST measurements (the mean temperature of the udder skin within a circle or a square, its standard deviation, range, minimum and maximum). The first circle (C1) was placed above the teat base on the surface of the right hind quarter and the second one (C2) in the same position on the surface of the left hind quarter.

The squares were placed just above the circles on the surfaces of the right and left hind quarters (marked as R1 and R2, respectively) - Fig. 1. However, because the surface available for temperature measurements was not always large enough (it was limited by the elements of the milking stalls), the temperature parameters within the squares were only taken for 6 out of 21 cows.

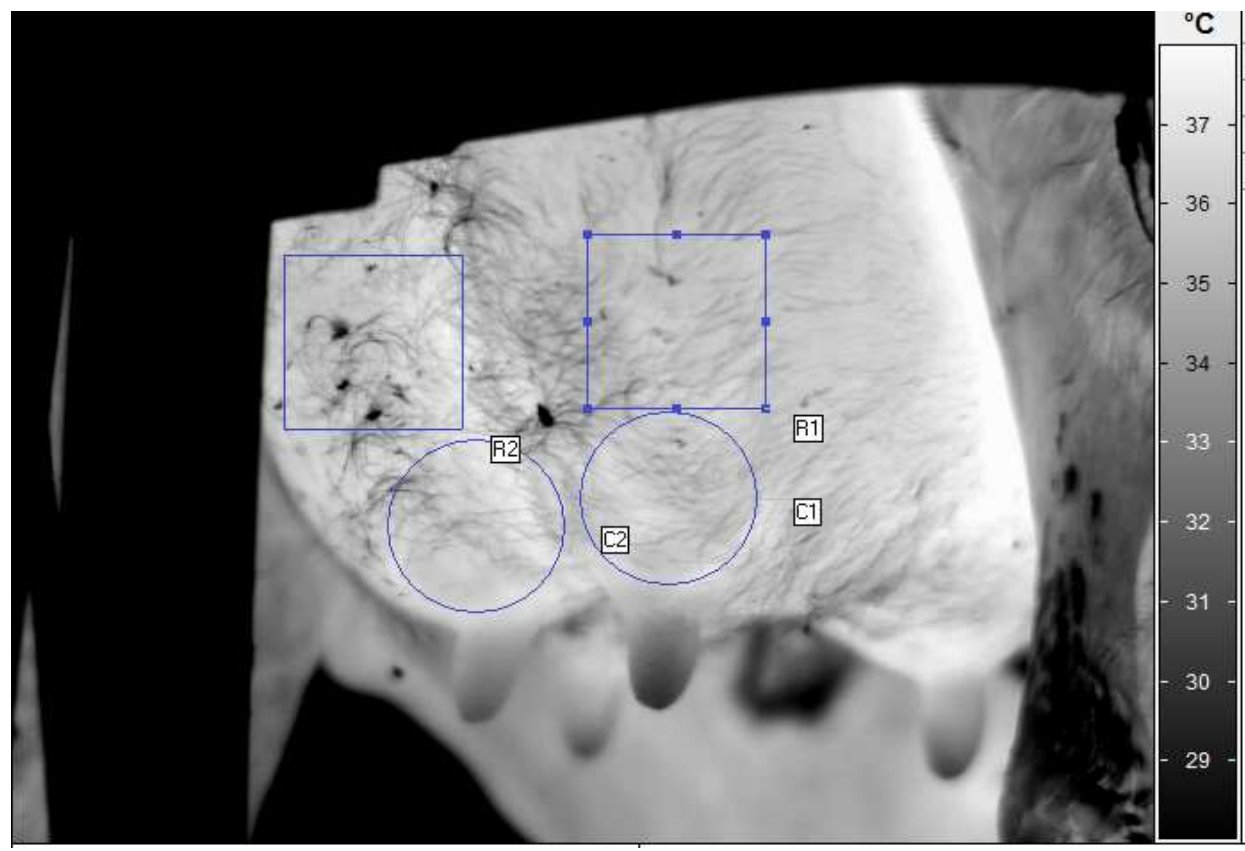

Fig. 1. The thermogram of the hind udder quarters with the circle and square geometric tools of the image analysis software placed on them. C1 - first circle geometric tool, C2 - second circle geometric tool, R1 - first square geometric tool, R2 - second square geometric tool

Ryc. 1. Termogram tylnych ćwiartek wymienia z naniesionymi kołami i kwadratami dostępnymi w programie do analizy obrazu. C1 - pierwsze koło, C2 - drugie koło, R1 - pierwszy kwadrat, R2 - drugi kwadrat 
For each temperature parameter (mean, standard deviation, range, minimum and maximum), their basic statistics including arithmetic mean, standard deviation, median, minimum and maximum were calculated. To verify the significance of the differences between the temperature means before and after milking for the circle geometric tool in the case of a normal distribution, the Student t-test for dependent samples was applied. The assumption about distribution normality was verified with the Shapiro-Wilk $W$ test. When the lack of a normal distribution for the circle geometric tool was found, the nonparametric equivalent of the Student $t$ test, i.e. the Wilcoxon rank signed test was used to check whether the udder SST distribution differed before and after milking in the same cow. The same non-parametric test was always used for the square geometric tool due to the low sample size. The difference in SST between the right and left hind quarters was also investigated for the circle and square geometric tools using the Student $t$ test for independent samples or the Mann-Whitney $U$ test. In the case of the former, its assumptions were first verified (normal distribution with the Shapiro-Wilk W test and variance homogeneity with the Levene's test). The significance level was declared at $P \leq 0.05$. The statistical analysis was carried out using the Statistica 12.5 program (StatSoft Inc., Tulsa, OK, USA).

\section{RESULTS}

The values of the measured temperature parameters for the circle and square geometric tools are presented in Table 1 and 2, respectively. Table 1 indicates that significant differences $(P \leq 0.05)$ in the mean values of the average temperature of the measured areas (circles) were found in the right and left hind quarters. The mean value of the average temperature was higher before milking $\left(36.48^{\circ} \mathrm{C}\right.$ and $36.61^{\circ} \mathrm{C}$ for the right and left hind quarter, respectively) than after it $\left(36.24^{\circ} \mathrm{C}\right.$ and $36.09^{\circ} \mathrm{C}$ for the right and left hind quarter, respectively). Statistically significant differences $(P \leq 0.05)$ in the mean values of other temperature parameters (minimum, range and standard deviation) were also observed in the left hind quarters before and after milking. The highest ranges of temperature values were recorded for the minimum temperature and temperature range of the circles placed on the right and left hind quarter surfaces both before and after milking.

Table 2 presents significant differences $(P \leq 0.05)$ in the mean values of the average temperature of squares in the left hind quarter. The mean value was higher before milking $\left(36.58^{\circ} \mathrm{C}\right)$ than after $\left(35.88^{\circ} \mathrm{C}\right)$. There was also one additional significant difference $(P \leq 0.05)$ in the minimum temperature of the squares before and after milking in the right hind quarter and three additional significant differences $(P \leq 0.05)$ in the left hind quarter (minimum, maximum and range). Like for circles, the highest temperature variability (measured as its range) was found for the minimum temperature and the difference between the maximum and minimum temperatures. However, these ranges were much lower than those for the circles.

The analysis of the differences in SST between the right and left hind quarters (Table 1) showed none but one parameter for which it was significant (temperature range after milking for the circle geometric tool). However, this difference was at the limit of statistical significance $(p=0.0497)$. 
Table 1. Temperature parameters for the circle geometric tool of the right and left hind-quarters $(n=21)$ Tabela 1. Wartości temperatury w obrębie kół dla prawej i lewej tylnej ćwiartki wymienia $(n=21)$

\begin{tabular}{|c|c|c|c|c|c|}
\hline $\begin{array}{l}\text { Variable } \\
\text { Zmienna }\end{array}$ & $\begin{array}{l}\text { Mean } \\
\text { Średnia }\end{array}$ & $\begin{array}{c}\text { SD } \\
\text { Odchylenie } \\
\text { standardowe }\end{array}$ & $\begin{array}{l}\text { Median } \\
\text { Mediana }\end{array}$ & $\begin{array}{l}\text { Minimum } \\
\text { Minimum }\end{array}$ & $\begin{array}{c}\text { Maximum } \\
\text { Maksimum }\end{array}$ \\
\hline & \multicolumn{5}{|c|}{${ }^{\circ} \mathrm{C}$} \\
\hline \multicolumn{6}{|c|}{ Before milking - Przed dojem } \\
\hline Mean R - Średnia P & $36.48^{a}$ & 0.56 & 36.57 & 35.29 & 37.26 \\
\hline Minimum $\mathrm{R}-$ Minimum $\mathrm{P}$ & 33.15 & 2.96 & 34.19 & 24.34 & 35.57 \\
\hline Maximum $\mathrm{R}$ - Maksimum $\mathrm{P}$ & 37.69 & 0.44 & 37.84 & 36.94 & 38.75 \\
\hline Range R - Zakres P & 4.15 & 2.18 & 3.54 & 2.20 & 11.05 \\
\hline SD R - Odchylenie standardowe P & 0.54 & 0.18 & 0.50 & 0.32 & 1.11 \\
\hline Mean - Średnia L & $36.61^{a}$ & 0.54 & 36.64 & 35.46 & 37.65 \\
\hline Minimum - Minimum L & $33.27^{a}$ & 2.27 & 33.42 & 26.28 & 36.41 \\
\hline Maximum - Maksimum L & 37.88 & 0.58 & 38.02 & 36.73 & 39.11 \\
\hline Range - Zakres L & $4.61^{\mathrm{a}}$ & 2.27 & 4.30 & 2.15 & 11.80 \\
\hline SD - Odchylenie standardowe L & $0.54^{a}$ & 0.13 & 0.51 & 0.32 & 0.81 \\
\hline \multicolumn{6}{|c|}{ After milking - Po doju } \\
\hline Mean R - Średnia P & $36.24^{\mathrm{b}}$ & 0.58 & 36.28 & 35.09 & 37.25 \\
\hline Minimum $\mathrm{R}$ - Minimum $\mathrm{P}$ & 32.74 & 2.71 & 33.90 & 24.51 & 35.11 \\
\hline Maximum $\mathrm{R}$ - Maksimum $\mathrm{P}$ & 37.59 & 0.56 & 37.53 & 36.65 & 38.54 \\
\hline Range R - Zakres P & $4.47^{\mathrm{A}}$ & 2.03 & 4.10 & 2.29 & 11.12 \\
\hline SD R - Odchylenie standardowe P & 0.58 & 0.22 & 0.55 & 0.32 & 1.34 \\
\hline Mean - Średnia L & $36.09^{b}$ & 0.61 & 36.10 & 34.93 & 37.47 \\
\hline Minimum - Minimum L & $32.22^{\mathrm{b}}$ & 1.74 & 32.20 & 29.51 & 34.82 \\
\hline Maximum - Maksimum L & 37.65 & 0.68 & 37.63 & 36.49 & 38.97 \\
\hline Range - Zakres L & $5.43^{\mathrm{Bb}}$ & 1.76 & 5.18 & 3.20 & 8.25 \\
\hline SD - Odchylenie standardowe L & $0.66^{\mathrm{b}}$ & 0.17 & 0.61 & 0.42 & 1.02 \\
\hline
\end{tabular}

Table 2. Temperature parameters for the square geometric tool of the right and left hind-quarters $(n=6)$ Tabela 2. Wartości temperatury w obrębie kwadratów dla prawej i lewej tylnej ćwiartki wymienia $(n=6)$

\begin{tabular}{|c|c|c|c|c|c|}
\hline \multirow[t]{2}{*}{$\begin{array}{l}\text { Variable } \\
\text { Zmienna }\end{array}$} & $\begin{array}{l}\text { Mean } \\
\text { Średnia }\end{array}$ & $\begin{array}{c}\text { SD } \\
\text { Odchylenie } \\
\text { standardowe }\end{array}$ & $\begin{array}{c}\text { Median } \\
\text { Mediana }\end{array}$ & $\begin{array}{l}\text { Minimum } \\
\text { Minimum }\end{array}$ & $\begin{array}{l}\text { Maximum } \\
\text { Maksimum }\end{array}$ \\
\hline & \multicolumn{5}{|c|}{${ }^{\circ} \mathrm{C}$} \\
\hline \multicolumn{6}{|c|}{ Before milking - Przed dojem } \\
\hline Mean R - Średnia P & 36.66 & 0.48 & 36.71 & 36.11 & 37.11 \\
\hline Minimum $\mathrm{R}$ - Minimum $\mathrm{P}$ & $35.05^{a}$ & 0.70 & 34.97 & 34.07 & 35.92 \\
\hline Maximum $\mathrm{R}$ - Maksimum $\mathrm{P}$ & 37.81 & 0.36 & 37.80 & 37.35 & 38.21 \\
\hline Range R - Zakres P & 2.76 & 0.64 & 2.93 & 1.86 & 3.45 \\
\hline SD R - Odchylenie standardowe P & 0.38 & 0.10 & 0.37 & 0.27 & 0.51 \\
\hline Mean - Średnia L & $36.58^{a}$ & 0.45 & 36.50 & 36.14 & 37.24 \\
\hline Minimum - Minimum L & $34.62^{a}$ & 0.88 & 34.75 & 33.03 & 35.48 \\
\hline Maximum - Maksimum L & $37.84^{a}$ & 0.50 & 37.67 & 37.29 & 38.71 \\
\hline Range - Zakres L & $3.22^{\mathrm{a}}$ & 0.83 & 3.25 & 1.96 & 4.53 \\
\hline SD - Odchylenie standardowe L & 0.47 & 0.13 & 0.42 & 0.36 & 0.69 \\
\hline \multicolumn{6}{|c|}{ After milking - Po doju } \\
\hline Mean R - Średnia P & 36.10 & 0.36 & 36.22 & 35.47 & 36.44 \\
\hline Minimum $\mathrm{R}$ - Minimum $\mathrm{P}$ & $34.05^{b}$ & 0.74 & 34.33 & 32.88 & 34.81 \\
\hline Maximum R - Maksimum P & 37.52 & 0.63 & 37.41 & 36.89 & 38.32 \\
\hline Range R - Zakres P & 3.47 & 1.12 & 3.50 & 2.16 & 5.44 \\
\hline SD R - Odchylenie standardowe P & 0.50 & 0.18 & 0.48 & 0.30 & 0.83 \\
\hline Mean - Średnia L & $35.88^{b}$ & 0.43 & 35.90 & 35.26 & 36.51 \\
\hline Minimum - Minimum L & $32.41^{b}$ & 1.95 & 33.02 & 29.33 & 34.78 \\
\hline Maximum - Maksimum L & $37.27^{b}$ & 0.47 & 37.25 & 36.60 & 37.86 \\
\hline Range - Zakres L & $4.15^{\mathrm{b}}$ & 1.07 & 4.29 & 2.46 & 5.65 \\
\hline SD - Odchylenie standardowe L & 0.57 & 0.08 & 0.58 & 0.46 & 0.66 \\
\hline
\end{tabular}

$\mathrm{a}, \mathrm{b}$ - different superscript letters within a column denote statistical significance at $\mathrm{P} \leq 0.05$ - różne małe litery w obrębie kolumny oznaczają różnice istotne statystycznie, przy $P \leq 0,05$. $R$ - right hind quarter $-P$ - prawa tylna ćwiartka wymienia, $L$ - left hind quarter - lewa tylna ćwiartka wymienia. 


\section{DISCUSSION}

Recently, an increasing number of studies have been performed to diagnose clinical and subclinical mastitis in dairy cattle using infrared thermography (Berry et al. 2003; Colak et al. 2008; Hovinen et al. 2008; Polat et al. 2010; Pezeshki et al. 2011; Metzner et al. 2014). The present preliminary study was aimed at finding whether machine milking affects SST of the rear udder quarters so that the establishment of the most optimum time for SST measurement in potential mastitis detection is possible. To achieve this goal, the images were taken under field conditions, i.e. without extensive cleaning or clipping of the udder surface before imaging. This approach was different than those adopted in other studies. Metzner et al. (2014) clipped and cleaned udder surface before imaging if necessary, similarly as Pezeshki et al. (2011), who removed all the debris present on the udder surface before taking images. Also, in the study by Berry et al. (2003) the udders of the examined animals were brushed, washed and dried before imaging if needed, whereas Polat et al. (2010) did thermographic examination in a dimmed room with a temperature of $18-23^{\circ} \mathrm{C}$. In the work by Hovinen et al. (2008) the images were taken before clinical examination of the udder and $40 \times 40$ pixel circles positioned just above the teats were used for the SST analysis. However, not all authors agree about the need for a cleaning of the udder surface before the measurement. The research presented by Franze et al. (2012) based on 552 Holstein-Friesian cows, showed that factors like air pressure, relative humidity and udder cleanliness do not have to be taken under consideration during the thermographic measurement of udder SST.

Due to the lack of udder clipping or extensive cleaning in the present study (as mentioned in the materials and methods section), temperature variation within the circles or squares among the examined animals (expressed as a standard deviation and a range) was much higher (Table 1) than those reported in other similar works (Berry et al. 2003; Colak et al. 2008; Polat et al. 2010; Metzner et al. 2014), although the mean values of the investigated parameters (such as an average temperature within a circle or a square or its range or standard deviation) were similar (vide e.g. Polat et al. 2010; Metzner et al. 2014). This may make direct comparisons between the studies difficult. It also means that in some cases, cleaning of the udder before measurement would be necessary in order to reduce the temperature variability on the skin surface. Cleaning should be performed at least 10 min prior to imaging but it could be problematic in practice (Metzner et al. 2014). As far as technical aspects are concerned, algorithms capable of the automatic determination of the udder quarter SST from the thermograms would be necessary to use a thermographic method under field conditions (Metzner et al. 2014).

Recently there have been presented many studies on the effect of machine milking on udder SST, however, most of them consider teat SST and not the SST of the udder quarters. Despite that, some comparisons with the results of the present study can be made. The first attempts at the thermographic measurements of the cow udder in response to machine milking were already made in 1985 (Hamann 1985). The study showed that conventional milking machines could cause a $2.0^{\circ} \mathrm{C}$ increase in teat-end temperature. The next study on teat skin temperature in 100 Friesian cows using liquid crystal sheets (Eichel 1992) revealed 
that the mean teat SST was about $32.0 \pm 0.5^{\circ} \mathrm{C}$ and that mechanical milking led to an about $1 \mathrm{~K}$ increase in the mean value of this temperature in approximately $90 \%$ of the examined animals but without any evidence of excessive stress caused by a piped milking machine. Similar results were obtained by Paulrud et al. (2002), who applied infrared thermography to assess milking-induced changes in teat tissue fluid circulation. In the work by Kunc et al. (1999) on the effect of different vacuum levels and rubber liner types (circular vs. triangular section) in an autotandem milking parlour on teat SST, it was found that lower vacuum (40 vs. $45 \mathrm{kPa}$ ) applied with circular section liners resulted in lower temperature changes, reducing the traumatization of the mammary gland at the same time.

The same effect was not observed in the case of triangular section liners. In their next study on the influence of the model of rubber teatcup liners on teat SST in 64 dairy cows milked in a $2 \times 10$ rapid exit herringbone milking parlour (vacuum $42.6 \mathrm{kPa}$ ), Kunc et al. (2000) observed the greatest increase in SST immediately after milking, irrespective of the liner manufacturer. With time (one to three minutes post milking), the teat SST decreased gradually and its highest reduction was found one minute post milking. Nevertheless, the teat SST did not assume its initial values until three minutes after milking and no visible teat injuries were caused by any of the liners investigated. In the study by Junga et al. (2016) on the udder and teat SST in 19 dairy cows, it was found that machine milking $(2 \times 2$ Westfalia tandem milking machine) caused a significant increase in the SST of both front and rear udder teats but not in the SST of the udder quarters, whereas Hanusová et al. (2016) analyzing the effect of two different partial vacuum levels (45 kPa and $40 \mathrm{kPa}$ ) on teat SST in six Holstein cows (bucket milking system) found that both levels increased the SST values immediately after milking (by 2.44 and $1.93 \mathrm{~K}$, respectively) and that the increase after afternoon milking was significant, while that after morning milking was not.

Moreover, the greatest teat SST decrease post milking occurred just two minutes after it. The subsequent study on the effect of machine milking and liner type on teat SST in cows (Paulrud et al. 2005) showed that the SST value was affected by the measurement position on the teat and the measurement time but not by overmilking. In general, SST significantly decreased along the teat (from its base to the end) and was affected by the type of liner after milking (the use of soft liners resulted in a lower SST than that of extended ones). In addition, the teat temperature fell by approximately $1.5 \mathrm{~K}$ as a result of teat preparation for milking irrespective of the teat position and was also affected by the machine milking itself but differently at different teat positions. Finally, the effect of liner type and overmilking on the difference between the temperature after milking and that before teat preparation was non-significant. In the last discussed work on the influence of five different milking units (including three herringbone milking parlours and two automatic milking systems) on the udder and teat SST in dairy cows, Vegricht et al. (2007) observed an increase in the SST of the udder and different teat parts (base, middle and tip) after milking compared with the pre-milking values. Its magnitude depended on the applied vacuum level and the type of milking system $(1.7-2.7 \mathrm{~K}$ and $0.9-1.7 \mathrm{~K}$ for a conventional parlour and an automatic milking system, respectively).

The influence of machine milking on udder SST by means of infrared thermography was also analyzed in other species than cattle. In Murciano-Granadina goats, Alejandro et al. (2014) investigated its effect on teat tissue and udder SST changes using point and circle geometric 
tools placed above the teat base in the latter case. The temperature before milking was lower $\left(34.33^{\circ} \mathrm{C}\right.$ and $34.32^{\circ} \mathrm{C}$ for points and circles, respectively) than that after milking $\left(35.93^{\circ} \mathrm{C}\right.$ and $35.92^{\circ} \mathrm{C}$ for points and circles, respectively). There were not any statistically significant differences between the two types of geometric tools used for the SST measurements. The authors also analyzed the effect of udder health status (healthy, mastitis caused by infection and unspecified mastitis without infection). The group of healthy goats also had a lower mean udder temperature before milking $\left(34.56^{\circ} \mathrm{C}\right.$ and $34.53^{\circ} \mathrm{C}$ for points and circles, respectively) than after it $\left(36.34^{\circ} \mathrm{C}\right.$ and $36.33^{\circ} \mathrm{C}$ for points and circles, respectively). The statistical significance of these differences was not mentioned but based on reported figures, it could be determined that they were significant $(P \leq 0.05)$. A second study on the effect of various factors on udder SST in Manchega and Lacaune sheep (Castro-Costa et al. 2014) revealed that the udder temperature measured using $55 \times 40$ pixel rectangles placed on both rear udder quarters significantly increased (by approx. $0.13^{\circ} \mathrm{C}$ ) as a result of milking, which could be explained by the hyperaemia caused by the manipulation of the udder. Such a relationship was also mentioned by Kunc et al. (2007) in their review of the application of infrared thermography to milking process monitoring. However, other studies have shown a decrease in udder SST after machine milking similarly as in the present work. E.g. Aljumaah et al. (2012) reported a significant decrease in both udder (up to $1.0 \mathrm{~K}$ ) and teat (up to $1.6 \mathrm{~K}$ ) SST values in lactating dromedary camels, which persisted until one hour post milking, whereas Stelletta et al. (2007) observed a $1.0 \mathrm{~K}$ decrease in the SST of posterior udder area in lactating Sarda ewes between the pre-milking and milking periods. Such SST differences in response to machine milking may be associated with different vacuum levels and different milk yields of investigated animals (Kunc et al. 2007).

As far as the differences in the SST temperatures between left and right hindquarters are concerned, we found only one such a case, but the difference was at the limit of statistical significance. Castro-Costa et al. (2014) did not record any difference between udder sides in sheep, similarly as Poikalainen et al. (2012) and Yang et al. (2015) in dairy cows, whereas Nakagawa et al. (2016) reported a significantly higher SST of the left hind quarter of multiparous Holstein cows compared with the right one in their work on Holstein, Jersey and Japanese Black cows in Japan.

\section{CONCLUSIONS}

Thermographic imaging of the udder surface revealed significant differences in the skin surface temperature before and after milking. Consequently, temperature measurement performed for potential mastitis detection should always be made at the same moment, as milking significantly affects skin surface temperature of the udder. The issue of udder preparation before measurement should also be resolved in future studies in order to reduce temperature variability among individuals and some standardization of the method would be necessary. Moreover, a larger sample of animals should be used to confirm the preliminary results obtained in the present work. 


\section{REFERENCES}

Alejandro M., Romero G., Sabater J.M., Díaz J.R. 2014. Infrared thermography as a tool to determine teat tissue changes caused by machine milking in Murciano-Granadina goats. Livest. Sci. 160, 178-185.

Aljumaah R.S., Samara E.M., Ayadi M. 2012. Influence of introducing machine milking on biothermal parameters of lactating camels (Camelus dromedarius). Ital. J. Anim. Sci. 11, e73.

Berry R.J., Kennedy A.D., Scott S.L., Kyle B.L., Schaefer A.L. 2003. Daily variation in the udder surface temperature of dairy cows measured by infrared thermography: Potential for mastitis detection. Can. J. Anim. Sci. 83, 687-693.

Castro-Costa A., Caja G., Salama A.A.K., Rovai M., Flores C., Aguiló J. 2014. Thermographic variation of the udder of dairy ewes in early lactation and following an Escherichia coli endotoxin intramammary challenge in late lactation. J. Dairy Sci. 97, 1377-1387.

Cockcroft P.D., Henson F.M.D., Parker C. 2000. Thermography of a septic metatarsophalangeal joint in a heifer. Vet. Rec. 146, 258-260.

Colak A., Polat B., Okumus Z., Kaya M., Yanmaz L.E., Hayirli A. 2008. Short communication: early detection of mastitis using infrared thermography in dairy cows. J. Dairy Sci. 91, 4244-4248.

Eichel H. 1992. Temperature of teat skin in dairy cows milked in piped milking parlour. Monatsh. Veterinarmed. 47, 193-195.

Franze U., Geidel S., Heyde U., Schroth A., Wirthgen T., Zipser S. 2012. Möglichkeiten des Einsatzes der Infrarot-Thermographie zur automatischen Gesundheitsüberwachung bei Milchkühen. Züchtungskunde 84, 158-170.

Hamann J. 1985. Infection-rate as affected by teat tissue-reactions due to conventional and nonconventional milking systems. Kiel. Milchwirtsch. Forschungsberichte 37, 426-430.

Hanusová J., Gálik R., Bod’o Š., Kunc P., Knížková I., Staroňová L. 2016. Analysis of quality milking process by thermographic method. Acta Univ. Agric. Silvic. Mendel. Brun. 64, 1149-1153.

Hovinen M., Siivonen J., Taponen S., Hänninen L., Pastell M., Aisla A.-M., Pyörälä S. 2008. Detection of clinical mastitis with the help of a thermal camera. J. Dairy Sci. 91, 4592-4598.

Hurnik J.F., De Boer S., Webster A.B. 1984. Detection of health disorders in dairy cattle utilizing a thermal infrared scanning technique. Can. J. Anim. Sci. 64, 1071-1073.

Hurnik J.F., Webster A.B., DeBoer S. 1985. An investigation of skin temperature differentials in relation to estrus in dairy cattle using a thermal infrared scanning technique. J. Anim. Sci. 61, 1095-1102.

Junga P., Travnicek P., Ruzbarsky J. 2016. Monitoring of the machine milking process with application of infrared thermography. MM Sci. J. 9, 985-988.

Kimmel E., Arkin H., Berman A. 1992. Evaporative cooling of cattle: transport phenomena and thermovision. Am. Soc. Agric. Biol. Eng. 92, 28-40.

Knizkova I., Kunc P. Knizek J., Novy Z. 1996. Evaluation of evaporative cooling on the changes of cattle surface body temperatures with use of thermovision. Zivocisna Vyroba 41, 433-439.

Knížková I., Kunc P., Koubková M., Flusser J., Dolezal O. 2002. Evaluation of naturally ventilated dairy barn management by a thermographic method. Livest. Prod. Sci. 77, 349-353.

Kunc P., Knizkova I. 2012. The use of infrared thermography in livestock production and veterinary field, in: Infrared thermography: Recent advances and future trends. Ed. M. Carosena. Sharjah, UAE, Bentham Science Publishers, SAIF Zone, 85-101.

Kunc P., Knizkova I., Koubkova M. 1999. The influence of milking with different vacuum and different design of liner on the change of teat surface temperature. Czech J. Anim. Sci. 44, 131-134.

Kunc P., Knížková I., Koubková M., Flusser J., Doležal O. 2000. Comparison of rubber liners by means of temperature states of teats. Res. Agric. Eng. 46, 104-107. 
Kunc P., Knizkova I., Prikryl M., Maloun J. 2007. Infrared thermography as a tool to study the milking process: a review. Agric. Trop. Subtrop. 40, 29-32.

Metzner M., Sauter-Louis C., Seemueller A., Petzl W., Klee W. 2014. Infrared thermography of the udder surface of dairy cattle: Characteristics, methods, and correlation with rectal temperature. Vet. J. 199, 57-62.

Nakagawa Y., Nassary N.A., Fukuyama K., Kobayashi I. 2016. Measurement of udder surface temperature in cows using infrared thermometer, in: Genetic and evolutionary computing. Proceedings of the Ninth International Conference on Genetic and Evolutionary Computing. Eds. T.T. Zin, J.C.-W. Lin, J.-S. Pan, P. Tin, M. Yokota. Yangon, Myanmar August 26-28, 2015. Vol. 1. Berlin, Springer, 429-434.

Nikkhah A., Plaizier J.C., Einarson M.S., Berry R.J., Scott S.L., Kennedy A.D. 2005. Short communication: Infrared thermography and visual examination of hooves of dairy cows in two stages of lactation. J. Dairy Sci. 88, 2749-2753.

Paulrud C.O., Clausen S., Andersen P.E., Bjerring M., Rasmussen M.D. 2002. Infrared thermography to evaluate milking induced alterations in teat tissue fluid circulation. J. Dairy Sci. 85(Suppl. 1), 334-334.

Paulrud C.O., Clausen S., Andersen P.E., Rasmussen M.D. 2005. Infrared thermography and ultrasonography to indirectly monitor the influence of liner type and overmilking on teat tissue recovery. Acta Vet. Scand. 46, 1.

Pezeshki A., Stordeur P., Wallemacq H., Schynts F., Stevens M., Boutet P., Peelman L.J., De Spiegeleer B., Duchateau L., Bureau F., Burvenich C. 2011. Variation of inflammatory dynamics and mediators in primiparous cows after intramammary challenge with Escherichia coli. Vet. Res. 42, 15-25.

Poikalainen V., Praks J., Veermäe L., Kokin E. 2012. Infrared temperature patterns of cow's body as an indicator for health control at precision cattle farming. Agron. Res. 10, 187-194.

Polat B., Colak A., Cengiz M., Yanmaz L.E., Oral H., Bastan A., Kaya S., Hayirli A. 2010. Sensitivity and specificity of infrared thermography in detection of subclinical mastitis in dairy cows. J. Dairy Sci. 93, 3525-3532.

Schaefer A.L., Cook N.J., Church J.S., Basarab J., Perry B., Miller C., Tong A.K.W. 2007. The use of infrared thermography as an early indicator of bovine respiratory disease complex in calves. Res. Vet. Sci. 83, 376-384.

Schaefer A.L., Cook N., Tessaro S.V., Deregt D., Desroches G., Dubeski P.L., Tong A.K.W., Godson D.L. 2004. Early detection and prediction of infection using infrared thermography. Can. J. Anim. Sci. 84, 73-80.

Schwartzkopf-Genswein K.S., Stookey J.M., Welford R. 1997. Behavior of cattle during hot-iron and freeze branding and the effects on subsequent handling ease. J. Anim. Sci. 75, 2064-2072.

Soroko M., Davies-Morel M.C.G. 2016. Equine thermography in practice. Boston, MA, CABI.

Stelletta C., Murgia L., Caria M., Gianesella M., Pazzona A., Morgante M. 2007. Thermographic study of the ovine mammary gland during different working vacuum levels. Ital. J. Anim. Sci. 6(Suppl. 1), 600.

Stewart M., Stafford K.J., Dowling S.K., Schaefer A.L., Webster J.R. 2008. Eye temperature and heart rate variability of calves disbudded with or without local anaesthetic. Physiol. Behav. 93, 789-797.

Stewart M., Webster J.R., Verkerk G.A., Schaefer A.L., Colyn J.J., Stafford K.J. 2007. Non-invasive measurement of stress in dairy cows using infrared thermography. Physiol. Behav. 92, $520-525$.

Unshelm J., Reinhart E., Platz S. 1992. Untersuchungen uber das Erfassen haltungsbedingter Schaden beim Rind mit Hilfe der Infrarottthermometrie. Tierärztl. Umsch. 47, 516-521.

Vainer B.G. 2012. Applications of infared thermography to medicine, in: Infrared thermography. Recent advances and future trends. Ed. M. Carosena. Sharjah, UAE, Bentham Science Publishers, SAIF Zone, 61-84. 
Vegricht J., Machálek A., Ambrož P., Brehme U., Rose S. 2007. Milking-related changes of teat temperature caused by various milking machines. Res. Agr. Eng. 53, 121-125.

Yang C.-H., Gu X.-H., Cao Z.-H., Zhang X.-J., Hao Y., Liu Y.-X., Shen L., Zhang Y.-T. 2015. Study on possibility of left and right quarter skin temperature difference as a detecting indicator for subclinical mastitis in dairy cows. Acta Vet. Zootech. Sin. 46, 1663-1670.

\begin{abstract}
The aim of the present study was to indicate if machine milking significantly affects udder skin surface temperature (SST) to establish the most optimum time for SST measurement in mastitis detection. A total of 21 healthy Polish Holstein-Friesian Black-andWhite cows were used in the study. The thermograms were recorded from the rear and bottom of the udders in a milking parlour before and after milking in the same cows. Two geometric tools (circles and squares) available in a computer program were used to measure an average SST, its minimum, maximum and standard deviation. The mean value of the average temperature of circles was higher $(P \leq 0.05)$ before milking $\left(36.48^{\circ} \mathrm{C}\right.$ and $36.61^{\circ} \mathrm{C}$ for the right and left hind quarter, respectively) than after it $\left(36.24^{\circ} \mathrm{C}\right.$ and $36.09^{\circ} \mathrm{C}$ for the right and left hind quarter, respectively). Also, the mean temperature of squares for the left hind quarter was higher $(P \leq 0.05)$ before milking $\left(36.58^{\circ} \mathrm{C}\right)$ than after it $\left(35.88^{\circ} \mathrm{C}\right)$. There was only one significant difference $(P \leq 0.05)$ in the temperature (circles) between the left and right hind quarters (the range of the temperature after milking). Consequently, temperature measurement performed for potential mastitis detection should always be made at the same moment, as milking significantly affects skin surface temperature of the udder.
\end{abstract}

This study was partly financed by the Polish Ministry of Science and Higher Education grant no.: 517-01-028-3962/17. We would like to thank Farm-M Partner Ltd. for its help in data processing. We would also like to thank The Board and Zootechnicians of the OHZ Lubiana for providing data for the study. 
